\title{
Subsurface North Atlantic warming as a trigger of rapid cooling events: evidence from the early Pleistocene (MIS 31-19)
}

\author{
I. Hernández-Almeida ${ }^{1}$, F.-J. Sierro ${ }^{2}$, I. Cacho ${ }^{3}$, and J.-A. Flores ${ }^{2}$ \\ ${ }^{1}$ Institute of Geography and Oeschger Centre for Climate Change Research, University of Bern, Erlachstrasse 9a, \\ 3012 Bern, Switzerland \\ ${ }^{2}$ Department of Geology, University of Salamanca, Plaza de la Merced s/n, Salamanca 37008, Spain \\ ${ }^{3}$ Department of Stratigraphy, Paleontology and Marine Geosciences, University of Barcelona, \\ C/Martí i Franquès s/n, 08028 Barcelona, Spain
}

Correspondence to: I. Hernández-Almeida (ivan.hernandez@giub.unibe.ch)

Received: 8 September 2014 - Published in Clim. Past Discuss.: 2 October 2014

Revised: 10 March 2015 - Accepted: 16 March 2015 - Published: 21 April 2015

\begin{abstract}
Subsurface water column dynamics in the subpolar North Atlantic were reconstructed in order to improve the understanding of the cause of abrupt ice-rafted detritus (IRD) events during cold periods of the early Pleistocene. We used paired $\mathrm{Mg} / \mathrm{Ca}$ and $\delta^{18} \mathrm{O}$ measurements of Neogloboquadrina pachyderma (sinistral - sin.), deep-dwelling planktonic foraminifera, to estimate the subsurface temperatures and seawater $\delta^{18} \mathrm{O}$ from a sediment core from Gardar Drift, in the subpolar North Atlantic. Carbon isotopes of benthic and planktonic foraminifera from the same site provide information about the ventilation and water column nutrient gradient. $\mathrm{Mg} / \mathrm{Ca}$-based temperatures and seawater $\delta^{18} \mathrm{O}$ suggest increased subsurface temperatures and salinities during icerafting, likely due to northward subsurface transport of subtropical waters during periods of weaker Atlantic Meridional Overturning Circulation (AMOC). Planktonic carbon isotopes support this suggestion, showing coincident increased subsurface ventilation during deposition of IRD. Subsurface accumulation of warm waters would have resulted in basal warming and break-up of ice-shelves, leading to massive iceberg discharges in the North Atlantic. The release of heat stored at the subsurface to the atmosphere would have helped to restart the AMOC. This mechanism is in agreement with modelling and proxy studies that observe a subsurface warming in the North Atlantic in response to AMOC slowdown during Marine Isotope Stage (MIS) 3.
\end{abstract}

\section{Introduction}

Rapid climate events in marine and continental sediments, as well as ice-core records, are a pervasive feature during the last glacial period (Dansgaard et al., 1993; Heinrich, 1988). Millennial-scale oscillations (Dansgaard-Oeschger (D-O) and Heinrich events) are characterized by abrupt shifts between warm and cold conditions, associated with icesheet oscillations, as evidenced by major ice-rafting events recorded in North Atlantic sediments (Grousset et al., 2001; Heinrich, 1988). The mechanism responsible for these fluctuations is not fully understood. Most accepted hypotheses relate rapid oscillations in the Atlantic Meridional Overturning Circulation (AMOC) to insulating effect of extensive iceshelves and sea-ice on the air-sea fluxes and/or to freshwater perturbations causing changes in the heat and salinity transport to the high-latitude northern North Atlantic (Ganopolski and Rahmstorf, 2001; Clark et al., 2001; Hátún et al., 2005; Li et al., 2005).

More recently, a number of studies have proposed that increased iceberg discharge during cold stadial events may have resulted from the destabilization of marine ice-shelves by a basal melting caused, in turn, by enhanced subsurface oceanic warming (Alvarez-Solas et al., 2010; Rasmussen and Thomsen, 2004; Marcott et al., 2011; Moros et al., 2002; Peck et al., 2008; Jonkers et al., 2010b; Ezat et al., 2014; Naafs et al., 2013). Model simulations indicate that weakening of deep convection at high latitudes in the North Atlantic results in a slow warming of intermediate depths (above 
$2500 \mathrm{~m}$ ) by downward diffusion of heat at low latitudes (Rühlemann et al., 2004). This heat is accumulated at the subsurface, and wind-induced circulation enables northward transport of warm and salty waters in the northern North Atlantic (Shaffer et al., 2004; Mignot et al., 2007; Liu et al., 2009). This mechanism involves the coupling of the AMOC with ice-sheet dynamics through an increase of the heat and salt export from low latitudes, and the warming of subsurface waters that would have acted as a positive feedback in ice-shelf collapse. General agreement between model and proxy evidence supports this explanation for abrupt climate shifts such as those associated with Heinrich and D-O events.

Application of $\mathrm{Mg} / \mathrm{Ca}$ palaeothermometry to deepdwelling planktonic foraminiferal species constitutes a potential recorder of subsurface conditions (Kozdon et al., 2009; Simstich et al., 2003; Volkmann and Mensch, 2001) for testing the feasibility of this hypothesis. Moreover, as foraminiferal $\delta^{18} \mathrm{O}$ is controlled by temperature and seawater $\delta^{18} \mathrm{O}\left(\delta^{18} \mathrm{O}_{\mathrm{sw}}\right)$, combining foraminiferal $\mathrm{Mg} / \mathrm{Ca}$ temperature reconstructions with $\delta^{18} \mathrm{O}$ from the same species and samples allow one to reconstruct $\delta^{18} \mathrm{O}_{\mathrm{sw}}$ as a proxy for salinity (Schmidt et al., 2004). Several palaeoceanographic studies using paired $\delta^{18} \mathrm{O}$ and $\mathrm{Mg} / \mathrm{Ca}$ measurements have been produced for the Marine Isotope Stage (MIS) 3 (Jonkers et al., 2010b; Peck et al., 2006 2008). However, studies with a similar approach are still required to understand subsurface temperature and circulation changes linked to AMOC reorganization during older time intervals, such as the early Pleistocene. Although the palaeoceanographic community has extensively studied climate disruptions during the most recent time periods, relatively little attention has been devoted to high-frequency climate variability in earlier periods when large Northern Hemisphere $(\mathrm{NH})$ ice-sheets were the same size as in the ate Pleistocene. Part of the gap of the study of these rapid climate oscillations in older time periods was due to the absence of high-resolution palaeoclimate records. However, during recent years, several studies carried out on International Ocean Discovery Program (formerly the Integrated Ocean Drilling Program) cores have found robust evidence of abrupt climate events (Bolton et al., 2010; Ferretti et al., 2010; Kleiven et al., 2011; Hernández-Almeida et al., 2012; Bartoli et al., 2006), with similar structure during transitions between cold (stadial) and warm (interstadial) phases of the D-O cycles as those found during the last glacial period.

To further constrain the relationship between subsurface ocean temperature and ice-sheet instabilities during the early Pleistocene, we present here a new millennial-scale reconstruction of the temperature and $\delta^{18} \mathrm{O}_{\mathrm{sw}}$ of the subsurface Atlantic inflow using paired $\mathrm{Mg} / \mathrm{Ca}$ and $\delta^{18} \mathrm{O}$ measurements of the planktonic foraminifera Neogloboquadrina pachyderma (sinistral - sin.) from IODP Site U1314. This is the first $\mathrm{Mg} / \mathrm{Ca}$ temperature record produced in the subpolar North Atlantic for the early Pleistocene. Previous palaeosea surface temperature (SST) records in the region are de- rived from planktonic foraminifera-based transfer functions (Hernández-Almeida et al., 2012) or alkenones (McClymont et al., 2008), but none of them give information about the thermocline conditions. The location of this core is at an ideal latitude for monitoring changes in ice-sheet mass balance, and $\mathrm{Mg} / \mathrm{Ca}$ values derived from $N$. pachyderma (sin.) allow one to record changes in the subsurface temperatures (upper thermocline, $\sim 200 \mathrm{~m}$ depth; Nürnberg, 1995) associated with oscillations in the AMOC. Our data suggest subsurface warming and salinity increases prior to and during the iceberg events, providing evidence of coupling between basal melting and ice-sheet collapse as a mechanism controlling the millennial-scale events in the early Pleistocene.

\section{Study site and materials}

Records were made using sediments from IODP Site U1314 $\left(56.36^{\circ} \mathrm{N}, 27.88^{\circ} \mathrm{W}, 2820 \mathrm{~m}\right.$ depth) from the southern Gardar Drift in the subpolar North Atlantic (Fig. 1a). Sedimentation rates average $9.3 \mathrm{~cm} \mathrm{ka}^{-1}$ from 1069 to $779 \mathrm{ka}$, dated by tuning our benthic $\delta^{18} \mathrm{O}$ curve to the benthic isotope stack of Lisiecki and Raymo (2005, hereinafter referred to as LR04) by using AnalySeries software (Paillard and Yiou, 1996; see Hernández-Almeida et al., 2012 for further details).

Site U1314 lies in the path of an extension of the North Atlantic Current (NAC), the Irminger Current (IC), which splits from the NAC and turns toward the Greenland coast. The core of this relatively warm and salty water mass is distinguishable by its properties vertically down to $700 \mathrm{~m}$ depth. As the IC travels westwards, it mixes with the colder and fresher waters of the East Greenland Current (EGC), becoming less saline and colder (Malmberg, 1985).

Although today the limit of winter sea-ice (Arctic Front) lies north of Site U1314, it is known to have migrated southward during glacials of the Pleistocene, bringing much cooler waters and potentially also sea-ice south of $60^{\circ} \mathrm{N}$ (Ruddiman, 1977). Today, modern hydrographic conditions at Site U1314 are characterized by seasonal water temperatures ranging between 7.7 and $11.7^{\circ} \mathrm{C}$ at $10 \mathrm{~m}$ depth and 7.4 and $8^{\circ} \mathrm{C}$ at $200 \mathrm{~m}$ (Locarnini et al., 2013) with nearly constant salinity of 35.1-35.2 practical salinity units (PSU, Antonov et al., 2006; Fig. 1b).

Winter convection of the cooled Atlantic surface waters in the Nordic seas results in the formation of North Atlantic Deep Water (NADW), which flows southward as the Iceland-Scotland Overflow Water (ISOW; Fig. 1a). This water mass flows at Site U1314 depth (Bianchi and McCave, 2000).

Subsurface water column conditions were determined through $\mathrm{Mg} / \mathrm{Ca}$ ratios and stable isotopes measured on deep-dwelling planktonic foraminifera N. pachyderma ( $\sin$.). This species inhabits and calcifies its shell in the subpolar North Atlantic at the upper thermocline, at $\sim 200 \mathrm{~m}$ depth (Kohfeld et al., 1996; Simstich et al., 2003; Nürnberg, 1995; 

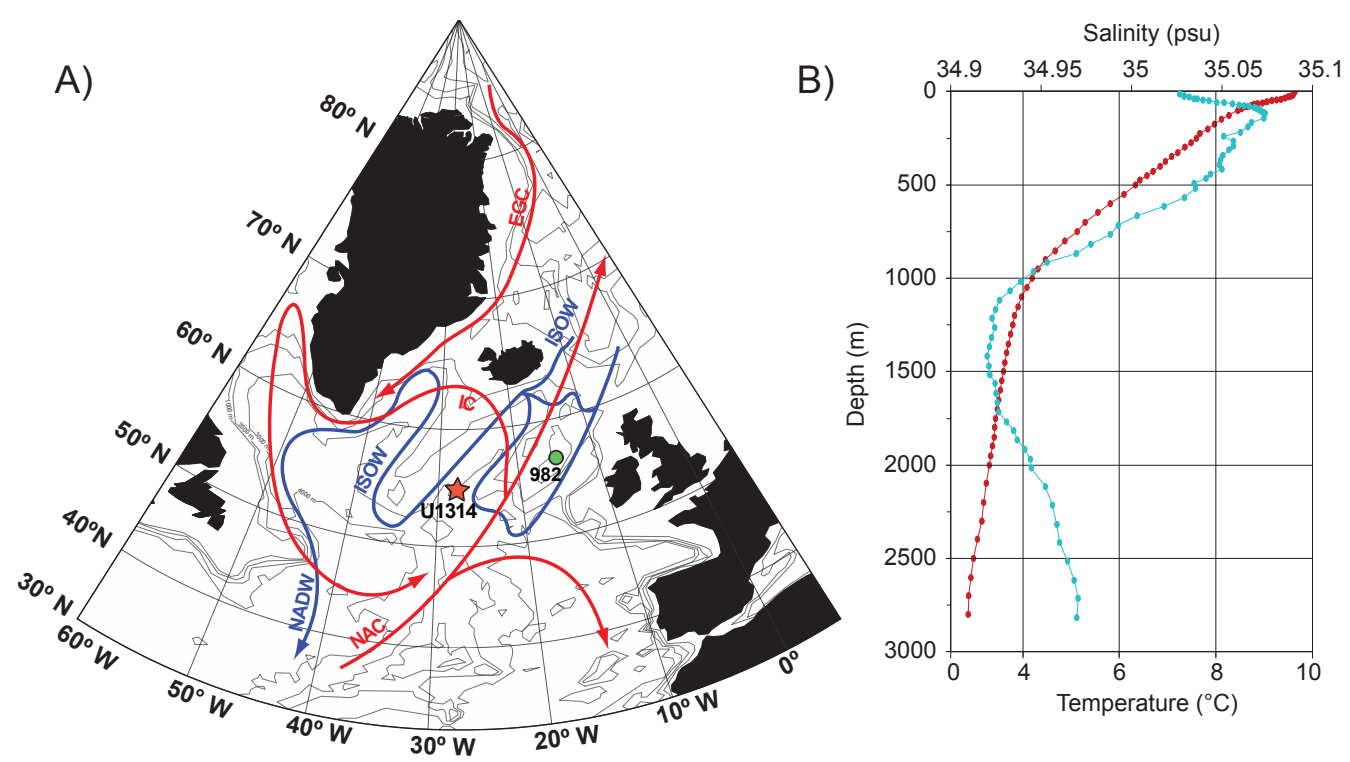

Figure 1. (a) Location of IODP Site U1314. Modern surface (red), and deep circulation (blue) in the North Atlantic: East Greenland Current (EGC), North Atlantic Current (NAC), Irminger Current (IC), Iceland-Scotland Overflow Water (ISOW), North Atlantic Deep Water (NADW). (b) Plots of temperature $\left({ }^{\circ} \mathrm{C}\right.$, red) and salinity (PSU, blue) versus depth obtained from the World Ocean Atlas 2013 (Locarnini et al., 2013; Zweng et al., 2013). Map generated with Ocean Data View v.3.4.3. software (Schlitzer, 2008).

Volkmann and Mensch, 2001). Therefore we assume that $\delta^{13} \mathrm{C}$ on deep-dwelling foraminifera $N$. pachyderma (sin.) provides information on the ventilation rates of the subsurface water mass (Hillaire-Marcel et al., 2011), while $\mathrm{Mg} / \mathrm{Ca}$ measurements of the same species reflect water temperature changes and combined with $\delta^{18} \mathrm{O}$ provides a record of seawater $\delta^{18} \mathrm{O}(\mathrm{sw})$ of the subsurface ocean (Peck et al., 2006).

Around 50-60 well-preserved tests of planktonic foraminifera $N$. pachyderma (sin.) (> $150 \mu \mathrm{m}$ size fraction, non-encrusted tests) were analysed in 542 samples for $\mathrm{Mg} / \mathrm{Ca}$ ratio following the procedure of Pena et al. (2005) which includes a reductive cleaning step. Dissolved samples were analysed using a Perkin Elmer Elan 6000 inductively coupled plasma mass spectrometer (ICP-MS) at the Scientific and Technological Centers of the University of Barcelona (CCiT-UB). External reproducibility for the $\mathrm{Mg} / \mathrm{Ca}$ ratio is estimated at $1.8 \%(2 \sigma)$ based on the analysis of high-purity gravimetrically prepared standard solution $\left(1.629 \mathrm{mmol} \mathrm{mol}^{-1}\right)$ measured routinely every four samples. Elemental ratios of $\mathrm{Mn} / \mathrm{Ca}$ and $\mathrm{Al} / \mathrm{Ca}$ ratios were analysed in parallel as quality controls for clay and Mn-rich mineral content. The recorded low values $\left(\mathrm{Mn} / \mathrm{Ca}<0.5 \mathrm{mmol} \mathrm{mol}^{-1} ; \quad \mathrm{Al} / \mathrm{Ca}<0.15 \mathrm{mmol} \mathrm{mol}^{-1}\right.$ ) and their low correlation with the $\mathrm{Mg} / \mathrm{Ca}$ ratios $\left(R^{2}=0.2\right.$ and 0.004 respectively) indicate that the cleaning protocol satisfactorily removed most of the contaminant phases. Final $\mathrm{Mg} / \mathrm{Ca}$ values were converted into temperatures values according to the equation of Elderfield and Ganssen (2000) ( $\mathrm{Mg}$ / Ca Temp; Table S1 in the Supplement).
Stable isotopes (carbon and oxygen; Table S1 in the Supplement) records from benthic and planktonic foraminifera correspond to Hernández-Almeida et al. (2013a, b, 2012). Analyses were carried out on planktonic foraminifera $N$. pachyderma (sin.) and on benthic foraminifera Cibicidoides spp. (mainly Cibicidoides wuellerstorfi) and Melonis pompilioides when the former was absent. An adjustment factor $\left(-0.11 \%\right.$ ofor $\delta^{18} \mathrm{O}$ and $+0.6 \%$ or $\left.\delta^{13} \mathrm{C}\right)$ calculated from replicates along the core was then applied to the $M$. pompilioides isotope values to produce a uniform isotope data set. Oxygen isotope values were then ice-volume corrected by scaling to the sea-level curve of LR04 using an last glacial maximum to late Holocene sea-level change of $120 \mathrm{~m}$ (Bintanja and van de Wal, 2008). Seawater $\delta^{18} \mathrm{O}$ was calculated introducing paired $\mathrm{Mg} / \mathrm{Ca}$-based temperatures and calcite $\delta^{18} \mathrm{O}$ from $N$. pachyderma (sin.) in the palaeotemperature equation of Shackleton $\left(1974 ; \delta^{18} \mathrm{O}_{\mathrm{sw}}\right.$; Table $\mathrm{S} 1$ in the Supplement). It has been widely demonstrated that planktonic species do not always precipitate calcite in equilibrium. Based on the $\delta^{18} \mathrm{O}$ measurements of seawater and $N$. pachyderma (sin.) tests from the Icelandic continental shelf, Smith et al. (2005) observed a $\delta^{18} \mathrm{O}$ disequilibrium offset of $0.25 \%$. Other authors have also observed a disequilibrium offset in the oxygen isotope composition of $N$. pachyderma (sin.) of $\sim 0.6 \%$ associated with post-gametogenic processes and thermal stratification of the water column in the Nordic seas (Nyland et al., 2006). However, Jonkers et al. (2010a) did not find any offset in sediment trap samples from the Irminger Sea. Taking into account that samples used in this study are very close to Site U1314, we did not apply 
Table 1. Summary of the changes in $\mathrm{Mg} / \mathrm{Ca}, \delta^{18} \mathrm{O}_{\mathrm{sw}}$ and planktonic $\delta^{13} \mathrm{C}$ during the IRD events. The amplitude of the change is calculated from the difference between the point where $\delta^{18} \mathrm{O}_{\mathrm{sw}}$ starts to increase prior to the IRD event and the $\delta^{18} \mathrm{O}_{\mathrm{sw}}$ maxima during the IRD event. The events are colour-coded, deep red showing the strongest change, and white the weakest.

\begin{tabular}{|c|c|c|c|}
\hline IRD Event & $\begin{array}{c}\text { Warming } \\
\mathrm{Mg} / \mathrm{Ca} \\
\left({ }^{\circ} \mathrm{C}\right)\end{array}$ & $\begin{array}{c}\text { Salinity } \\
\delta^{18} \mathrm{O}_{\text {sw }} \\
(\%)\end{array}$ & $\begin{array}{c}\text { Ventilation } \\
\delta^{13} \mathrm{C}_{\text {plank }} \\
(\%)\end{array}$ \\
\hline MIS $30(\sim 1052 \mathrm{ka})$ & 5.4 & 1.7 & 0.4 \\
\hline MIS 29 ( 1033 ka) & 4 & 1.4 & 0.4 \\
\hline MIS 29 ( 1020 ka) & 0.92 & 1.3 & 0.7 \\
\hline MIS 28 ( 1012 ka) & 1.7 & 0.7 & 0.4 \\
\hline MIS 28 ( 1004 ka) & 6.2 & 0.9 & 0.5 \\
\hline MIS 27 ( 995 ka) & 2.9 & 1.5 & 0.9 \\
\hline MIS 27 ( 981 ka) & 3.6 & 1.1 & 0.3 \\
\hline MIS 27 ( 970 ka) & 3.1 & 1.5 & 0.3 \\
\hline MIS 26 ( 961 ka) & 1.8 & 1.2 & 0.02 \\
\hline MIS 24 ( 931 ka) & 2.8 & 0.7 & 0.3 \\
\hline MIS 24 ( 924 ka) & 4 & 1.8 & 0.2 \\
\hline MIS 23 ( 910 ka) & 2.9 & 1.3 & 0.5 \\
\hline MIS 22 ( 888 ka) & 3.2 & 1.5 & 0.1 \\
\hline MIS 22 ( 870 ka) & 6.3 & 2 & 0.4 \\
\hline MIS 21 ( 842 ka) & 6.4 & 1.6 & 0.4 \\
\hline MIS 21 ( 830 ka) & 0.1 & 0.6 & 0.4 \\
\hline MIS 21 ( 828 ka) & 0.5 & 0.8 & 0.3 \\
\hline MIS 21 ( 820 ka) & 1.7 & 1.1 & 0.5 \\
\hline MIS 21 ( 815 ka) & 3 & 0.8 & 0.2 \\
\hline MIS 21 ( 805 ka) & 1.5 & 1.2 & 0.3 \\
\hline
\end{tabular}

any correction factor to our calculated $\delta^{18} \mathrm{O}_{\mathrm{sw}}$. Contradicting studies indicate that this issue is not well constrained, with a need for further studies. Due to the uncertainties in $N$. pachyderma (sin.) "vital effect" and low SST during the midPleistocene transition that may overestimate the $\delta^{18} \mathrm{O}_{\text {sw }}$ values, we suggest caution when interpreting in absolute terms.

\section{Results}

$\mathrm{Mg} / \mathrm{Ca}$ ranges between 0.7 and $1.25 \mathrm{mmol} \mathrm{mol}^{-1}$, and $\mathrm{Mg} / \mathrm{Ca}$-derived palaeotemperatures range between 1.9 and $12.3{ }^{\circ} \mathrm{C}$ (Fig. 2). The $\mathrm{Mg} / \mathrm{Ca}$ and $\delta^{18} \mathrm{O}_{\text {sw }}$ records show different patterns after and before MIS 25. From MIS 31 to MIS 25, the amplitude of the glacial-to-interglacial (G-IG) changes is low; temperatures and $\delta^{18} \mathrm{O}_{\mathrm{sw}}$ are stable, only punctuated by frequent millennial-scale oscillations, with temperature decreases of $\sim 3{ }^{\circ} \mathrm{C}$ and $\delta^{18} \mathrm{O}_{\text {sw }}$ increases up to $1 \%$. After MIS 25, the amplitude of hydrographic changes was larger, with $\delta^{18} \mathrm{O}_{\mathrm{sw}}$ increased by $\sim 0.5-1 \%$, and temperature reaching maxima up to $12^{\circ} \mathrm{C}$ between MIS 25 and 21. During this interval, there is also a pervasive suborbital variability, especially during glacial onset and during MIS 21. Ice-rafting episodes are characterized by relatively warm and saltier subsurface waters at the Gardar Drift. Rapid temperature and $\delta^{18} \mathrm{O}_{\mathrm{sw}}$ increases are observed before the ice-rafted detritus (IRD) deposition, e.g. at 1060, 995, 924, $880 \mathrm{ka}$, or shortly after the iceberg discharge started (Fig. 3). There are exceptions, and some events do not show this pattern, like at $\sim 832$ and $828 \mathrm{ka}$, subsurface warming is not observed, but there is increase in $\delta^{18} \mathrm{O}_{\mathrm{sw}}$ (Table 1).

The most important feature of the difference between benthic and planktonic $\delta^{13} \mathrm{C}\left(\Delta \delta^{13} \mathrm{C}\right)$ are the abrupt decreases of $\sim 1 \%$ o during IRD events, when values are around $0 \%$. During warmer periods, $\Delta \delta^{13} \mathrm{C}$ ranges between +1 and $1.4 \%$ o (Fig. 4).

\section{Discussion}

Palaeotemperature estimates based on $\mathrm{Mg}$ / Ca of N. pachyderma (sin.) at Site U1314 indicate that many of the IRD events were characterized by an abrupt subsurface warming (Fig. 2). The magnitude of this warming is not always the same across the studied interval, ranging between 2.5 and $8^{\circ} \mathrm{C}$. The $\delta^{18} \mathrm{O}_{\text {sw }}$ shows repeatedly higher values, indicating saltier waters during IRD deposition. Although these changes in temperature and salinity were simultaneous with the IRD events, in some cases (e.g. at $995 \mathrm{ka}$ ), subsurface waters started to warm up and become saltier even before the icerafting. The positive excursions of the $\delta^{13} \mathrm{C}$ signal from $N$. pachyderma (sin.) during these events were interpreted to indicate increasing subsurface ventilation in the North Atlantic (Hernández-Almeida et al., 2013b; Fig. 2). Similar conditions of better ventilation at intermediate depths during IRD deposition are also evident from benthic $\delta^{13} \mathrm{C}$ in Site 982 on the Rockall Plateau (Venz et al., 1999), which was suggested to be related to changes in the production of Glacial North Atlantic Intermediate Water (GNAIW) (Fig. 2). Strong coupling between the $\mathrm{Mg} / \mathrm{Ca}$ temperatures and $\delta^{18} \mathrm{O}_{\text {sw }}$ fluctuations and subsurface circulation may reflect a change in the AMOC.

The accumulation of subsurface warming during icerafting events would have corresponded with a rapid devel- 


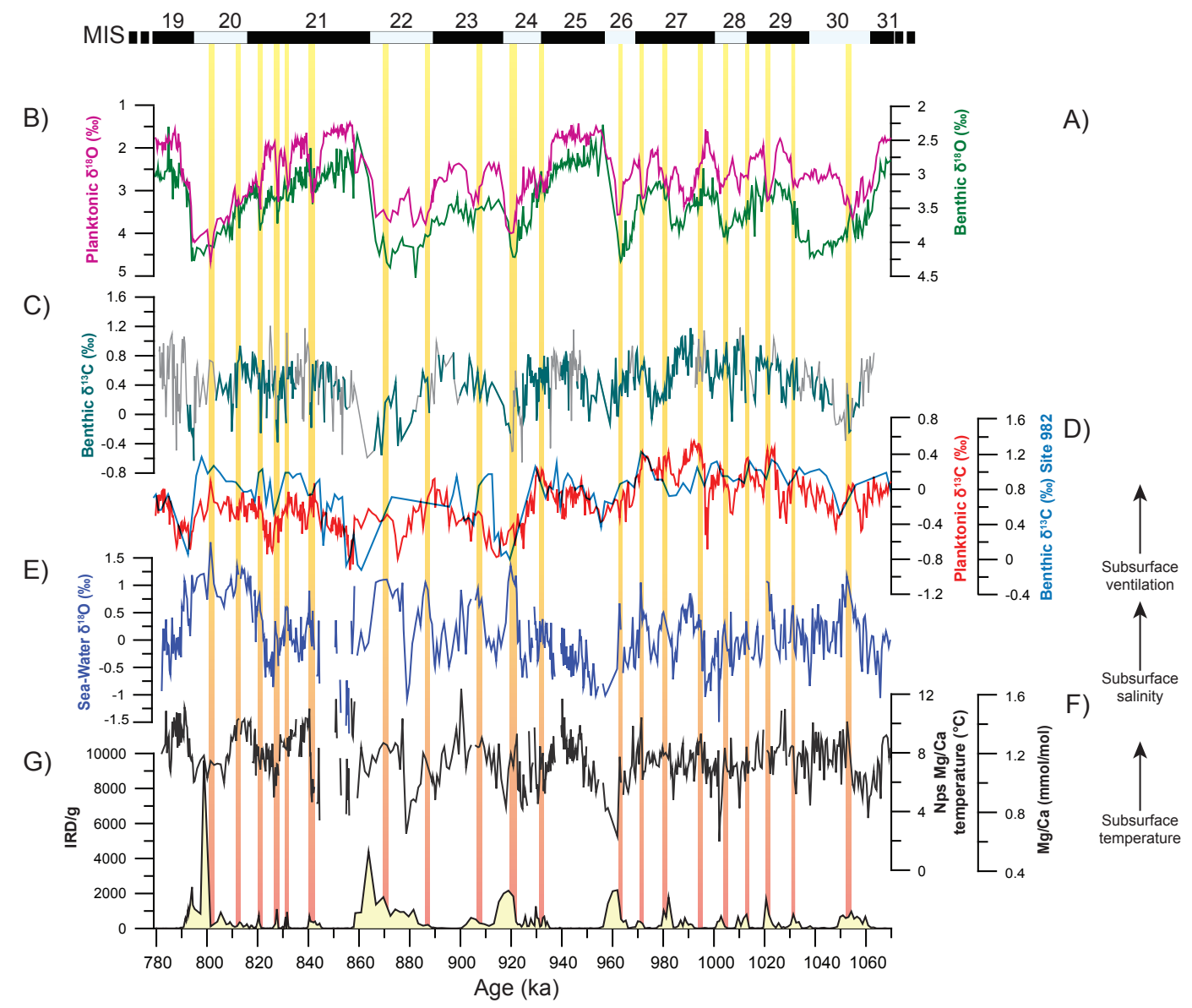

Figure 2. Data for IODP Site U1314 spanning MIS 31-19 vs. age. From top to bottom: (a) benthic (Hernández-Almeida et al., 2013a) and (b) planktonic $\delta^{18} \mathrm{O}$ (Hernández-Almeida et al., 2012); (c) benthic $\delta^{13} \mathrm{C}$ (Hernández-Almeida et al., 2013a) (Cibicidoides spp., green; adjusted M. pompilioides, grey); (d) planktonic $\delta^{13} \mathrm{C}$ (red) (Hernández-Almeida et al., 2013b) vs. benthic $\delta^{13} \mathrm{C}$ from Site 982 (blue) (Venz et al., 1999); (e) $\delta^{18} \mathrm{O}_{\mathrm{sw}}$ reconstruction from paired $\mathrm{Mg} / \mathrm{Ca}$ and $\delta^{18} \mathrm{O}$ measurements of the planktonic foraminifera Neogloboquadrina pachyderma (sin.); (f) Mg / Ca-derived palaeotemperature calculated using exponential temperature equation of Elderfield and Ganssen (2000). (g) IRD/g (Hernández-Almeida et al., 2012). Vertical bars indicate maxima of the $\delta^{18} \mathrm{O}_{\mathrm{sw}}$ associated with each subsurface heat and salt increase.

opment of the thermocline that stabilizes the water column and via intense basal melting and thinning of marine iceshelves provokes a large-scale instability of the ice-sheets and retreat of the grounding line. With the destruction of iceshelves, ice streams can surge, leading to increased iceberg production. The ice-sheets located in regions with relatively mild conditions and high precipitation rates, such as Scandinavia and Iceland, are indeed very sensitive to millennial climate variability, and then respond quickly to warmer conditions producing iceberg discharges (Marshall and Koutnik, 2006). The difference between benthic and planktonic $\delta^{13} \mathrm{C}$ $\left(\Delta \delta^{13} \mathrm{C}\right)$, used to indicate the nutrient gradient between subsurface and bottom water (Charles et al., 2010), gives additional information about the ventilation of subsurface and deep waters. The short-term periods of low $\Delta \delta^{13} \mathrm{C}$ values $(\sim 0 \%)$ during IRD discharges suggest water column vertical mixing and formation of the GNAIW south of the Arctic Front.
After iceberg calving decreased, the sudden release of heat accumulated at the subsurface and broke the upper stratification (Mignot et al., 2007). Inflowing warm and salty Atlantic waters were again in contact with the surface ocean, and there was an efficient release of heat to the atmosphere, resulting in an intensified AMOC characterized by deeper and stronger deep-water circulation (Schmidt et al., 2006; Liu et al., 2009). Onset of deep convection in the Nordic seas and NADW production led to a shutdown of GNAIW production (Venz et al., 1999). The nutrient gradient profile shows rapid increases up to $1.4 \%$ reflecting the establishment of a strong nutricline between deep and subsurface waters (Fig. 4). The switch to deep convection and a strong AMOC overshooting caused a decrease in subsurface temperatures and $\delta^{18} \mathrm{O}_{\mathrm{sw}}$, suggesting the return toward a "normal water column" state.

Although the mechanism that characterizes the subsurface climate instabilities involves higher $\mathrm{Mg} / \mathrm{Ca}$ temperatures and planktonic $\delta^{13} \mathrm{C}$ and $\delta^{18} \mathrm{O}_{\mathrm{sw}}$, some of the events are miss- 

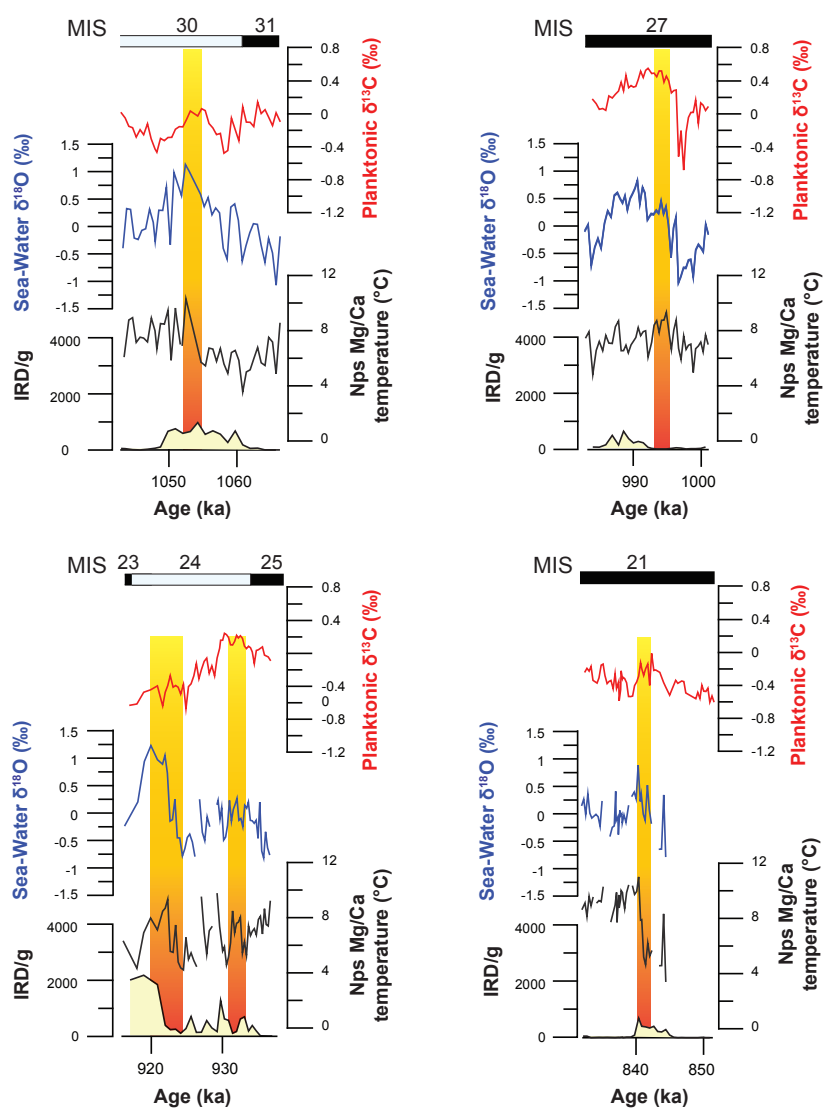

Figure 3. Comparison between $\mathrm{Mg} / \mathrm{Ca}$ palaeotemperature, $\delta^{18} \mathrm{O}_{\text {sw }}$, planktonic $\delta^{13} \mathrm{C}$ and IRD/g for Site U1314 during specific intervals.

ing some of these features. At $\sim 832$ and $828 \mathrm{ka}$, IRD events are not clearly accompanied by subsurface warming, while changes in $\delta^{13} \mathrm{C}$ and $\delta^{18} \mathrm{O}_{\mathrm{sw}}$ are evident (Table 1). This could imply that the more active subsurface depth ventilation was due to brine rejection during the wintertime sea-ice production, as occurs in high-latitude seas (Aagaard and Carmack, 1989; Horikawa et al., 2010). However, this alternate mechanism to explain the eventual higher density of subsurface waters in absence of warmer waters is speculative, and more robust evidence of brine rejection during sea-ice formation are needed. We are still uncertain about the driving mechanism that drives northward transport of warm and salty subsurface waters during episodes of weak AMOC. We suggest that analogous mechanisms involving ice-shelf and sea-ice expansion in the $\mathrm{NH}$ that are invoked to explain D-O cycles during the last glacial period (Petersen et al., 2013), also operated during the early Pleistocene. Growing ice-shelves in the subpolar North Atlantic during the onset of glaciations would have changed land surface albedos producing a reduction of air sea temperature (Broccoli and Manabe, 1987). This cooling would have increased the extent and thickness of sea-ice, resulting in a higher insulation of the surface ocean (Li et al., 2005; Kaspi et al., 2004), causing convection shutdown in the high-latitude North Atlantic and reduced NADW formation. A weakened subpolar gyre circulation would have supplied less cold and less fresh water to the Atlantic inflow to the Nordic seas, making it saltier (Thornalley et al., 2009; Hátún et al., 2005). Warm and salty waters accumulating at the subsurface would have been eventually transported poleward as there was still convection, although at intermediate depths, and finally this would have caused a temperature inversion and higher salinity at subsurface depths in the subpolar North Atlantic (Shaffer et al., 2004). Alternatively, abrupt slowdown of the AMOC may respond to different mechanisms including internal oscillation regulated via atmospheric $\mathrm{CO}_{2}$ concentration and Southern Ocean wind intensifications (Banderas et al., 2012; AlvarezSolas et al., 2011).

Several modelling and palaeoclimate studies also show intermediate or subsurface warming in the North Atlantic during IRD events as a response to AMOC reorganization (Liu et al., 2009; Mignot et al., 2007; Brady and Otto-Bliesner, 2011), accompanied by a southward shift in the convection cell from the Nordic seas to the subpolar North Atlantic (Brady and Otto-Bliesner, 2011; Venz et al., 1999; Voelker et al., 2010; Oppo and Lehman, 1993). This scenario characterized by a temperature inversion represents an analogous situation to modern conditions in Arctic Ocean. In this region, Atlantic waters flowing via the West Spitsbergen Current cause an Atlantic-derived temperature and salinity maximum at $200-500 \mathrm{~m}$ water depth, under the permanent sea-ice cover (Bauch et al., 1997).

Temperature sensitive proxies from other North Atlantic sites display similar features that are interpreted as subsurface warming conditions prior to ice-rafting events and deglaciations during the last glacial period and the Holocene. Risebrobakken et al. (2011) documented intensified subsurface warming in the Nordic seas using planktonic foraminifera fauna as a response to the reduced strength of the AMOC through the deglaciation and the early Holocene. $\mathrm{Mg} / \mathrm{Ca}$-derived temperatures from N. pachyderma (sin.) in two cores from the north-east Atlantic also support the inferred warming during Heinrich events. These records show upper ocean stratification and high subsurface temperatures initiated during ice-rafting events (Jonkers et al., 2010b; Peck et al., 2008). Jonkers et al. (2010b) explained the low planktonic $\delta^{13} \mathrm{C}$ values of $N$. pachyderma during these events as a result of reduced ventilation of subsurface waters due to the insulating effect of a meltwater lens and/or a sea-ice layer. Our high planktonic $\delta^{13} \mathrm{C}$ values during these rapid cooling events, however, indicate that more intense subsurface ventilation and/or nutrient depleted subtropical waters were exported to the subpolar North Atlantic, which is supported by the similarity with the intermediate water $\delta^{13} \mathrm{C}$ signal from Site 982 (Venz et al., 1999; Fig. 2). We argue that such disagreement between planktonic $\delta^{13} \mathrm{C}$ profiles could be explained by the southward shift of the polar front as far as $42^{\circ} \mathrm{N}$ during cold periods of the Upper Pleistocene (Rud- 


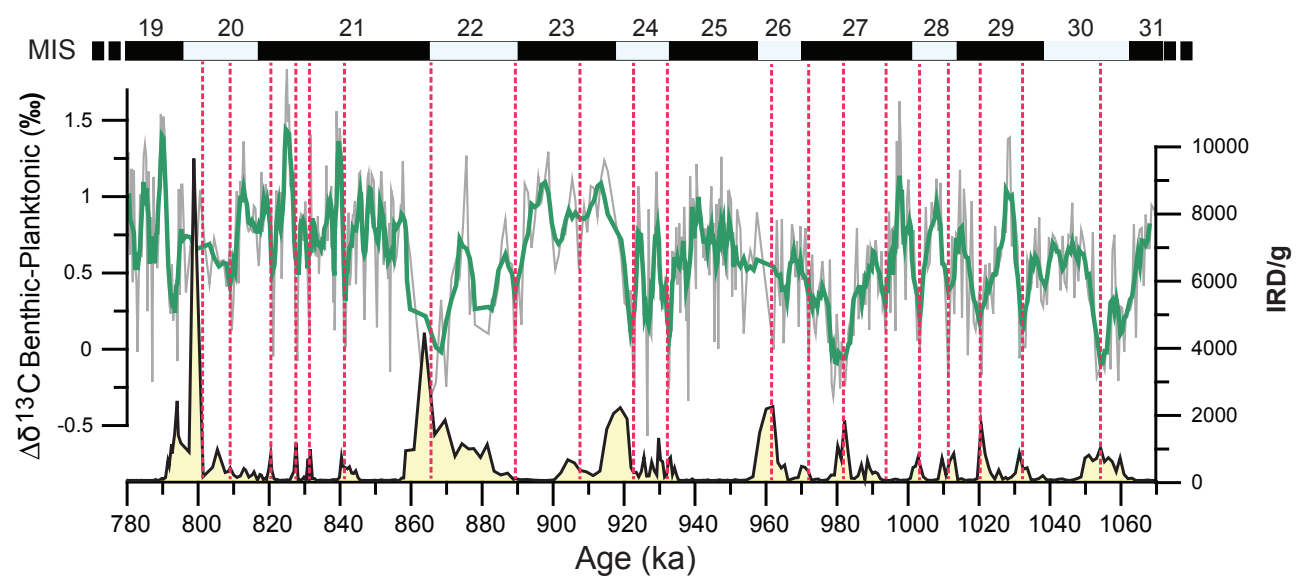

Figure 4. Data for IODP Site U1314 spanning MIS 31-19 vs. age. (a) $\Delta \delta^{13} \mathrm{C}_{\mathrm{b}-\mathrm{p}}$ (b: benthic (i.e. C. wuellerstorfi and M. pompilioides), p: planktonic N. pachyderma (sin)); (b) IRD/g (Hernández-Almeida et al., 2012).

diman and McIntyre, 1981; Eynaud et al., 2009), limiting the fraction of nutrient depleted subtropical waters exported northward (Mix and Fairbanks, 1985) compared to the early Pleistocene.

Similar warm conditions during Heinrich events and stadials are also evident from benthic fauna and $\mathrm{Mg} / \mathrm{Ca}$ ratios in benthic foraminifera from the Nordic seas, indicating that warming was probably extended to intermediate depths (below $1000 \mathrm{~m}$ ) by downward diffusion of subtropical ocean heat during times of slow North Atlantic overturning (Rasmussen and Thomsen, 2004; Marcott et al., 2011; Ezat et al., 2014). These results are in agreement with subsurface warming events at the subtropics during Heinrich 1 (Schmidt et al., 2012). All of these observations suggest that subsurface warming was a basin-wide phenomenon during periods of reduced AMOC in MIS 3. To better constrain this scenario for the early Pleistocene, more subsurface marine records situated in key regions from the North Atlantic are required. The proposed scenario is in agreement with modelling studies that reveal basal melting of the ice-shelf and periodic pulses of iceberg discharge as a response to strong reduction of the AMOC (Mignot et al., 2007; Shaffer et al., 2004; AlvarezSolas et al., 2010; Manabe and Stouffer, 1997).

Finally, from the similarity of the palaeoclimatic records with the model simulations and modern observations, we argue that observed increased subsurface ocean warming could play a leading role in the massive break-up of ice-shelves in the Antarctic Ocean (Vaughan and Doake, 1996; Rignot and Jacobs, 2002; MacAyeal et al., 2003).

\section{Conclusions}

The $\mathrm{Mg} /$ Ca-derived palaeotemperature and $\delta^{18} \mathrm{O}_{\text {sw }}$ oscillations prior to and during IRD discharges at Site U1314 across the early Pleistocene (MIS 31-19) are related to changes in subsurface circulation. The mechanism operating during episodes of rapid climate cooling consists of a reduction in the AMOC during periods of extensive ice-shelves and sea-ice in the subpolar North Atlantic. Deep water convection sites shifted south of the polar front and production of GNAIW increased at the expense of NADW. Poleward transport of warm and salty subsurface subtropical waters during these episodes thinned and destabilized ice-shelves creating pulses of iceberg discharge. Heat accumulated at the subsurface was suddenly released to the atmosphere when the ice-sheet collapsed, resulting in an intensified AMOC. Analogous mechanisms based on subsurface warming as a trigger for millennial-scale climate variability were proposed for Heinrich events or D-O cycles recorded during the late glacial period (Alvarez-Solas et al., 2010; Shaffer et al., 2004), reflecting that rapid switches of the AMOC also occurred during the early Pleistocene.

\section{The Supplement related to this article is available online at doi:10.5194/cp-11-687-2015-supplement.}

Acknowledgements. This work was funded by Ministerio de Ciencia e Innovación Project GRACCIE (CONSOLIDERINGENIO CSD2007-00067) and CGL2011-26493. I. Cacho thanks the ICREA Academia funding form the Generalitat de Catalunya. We are grateful to Leopoldo Pena and Gemma Herrera for their assistance with laboratory work at the University of Barcelona, and to Martin Grosjean for his comments and suggestions on the manuscript. This research used samples from IODP Expedition 306.

Edited by: T. Kiefer 


\section{References}

Aagaard, K. and Carmack, E. C.: The role of sea ice and other fresh water in the Arctic circulation, J. Geophys. Res.-Oceans, 94, 14485-14498, doi:10.1029/JC094iC10p14485, 1989.

Alvarez-Solas, J., Charbit, S., Ritz, C., Paillard, D., Ramstein, G., and Dumas, C.: Links between ocean temperature and iceberg discharge during Heinrich events, Nature Geosci., 3, 122-126, 2010.

Alvarez-Solas, J., Charbit, S., Ramstein, G., Paillard, D., Dumas, C., Ritz, C., and Roche, D. M.: Millennial-scale oscillations in the Southern Ocean in response to atmospheric $\mathrm{CO}_{2}$ increase, Global Planet. Change, 76, 128-136, 2011.

Antonov, J. I., Locarnini, R. A., Boyer, T. P., Mishonov, A. V., and Garcia, H. E.: World Ocean Atlas 2005, Volume 2: Salinity, edited by: Levitus, S., NOAA Atlas NESDIS, 62, 182 pp., 2006.

Banderas, R., Álvarez-Solas, J., and Montoya, M.: Role of $\mathrm{CO}_{2}$ and Southern Ocean winds in glacial abrupt climate change, Clim. Past, 8, 1011-1021, doi:10.5194/cp-8-1011-2012, 2012.

Bartoli, G., Sarnthein, M., and Weinelt, M.: Late Pliocene millennial-scale climate variability in the northern North Atlantic prior to and after the onset of Northern Hemisphere glaciation, Paleoceanography, 21, PA4205, doi:10.1029/2005pa001185, 2006.

Bauch, D., Carstens, J., and Wefer, G.: Oxygen isotope composition of living Neogloboquadrina pachyderma (sin.) in the Arctic Ocean, Earth Planet. Sci. Lett., 146, 47-58, 1997.

Bianchi, G. G. and McCave, I. N.: Hydrography and sedimentation under the deep western boundary current on Björn and Gardar Drifts, Iceland Basin, Mar. Geol., 165, 137-169, 2000.

Bintanja, R. and van de Wal, R. S. W.: North American ice-sheet dynamics and the onset of 100,000-year glacial cycles, Nature, 454, 869-872, 2008.

Bolton, C. T., Wilson, P. A., Bailey, I., Friedrich, O., Beer, C. J., Becker, J., Baranwal, S., and Schiebel, R.: Millennialscale climate variability in the subpolar North Atlantic Ocean during the late Pliocene, Paleoceanography, 25, PA4218, doi:10.1029/2010pa001951, 2010.

Brady, E. and Otto-Bliesner, B.: The role of meltwater-induced subsurface ocean warming in regulating the Atlantic meridional overturning in glacial climate simulations, Clim. Dynam., 37, 1517-1532, doi:10.1007/s00382-010-0925-9, 2011.

Broccoli, A. and Manabe, S.: The influence of continental ice, atmospheric $\mathrm{CO}_{2}$, and land albedo on the climate of the last glacial maximum, Clim Dynam., 1, 87-99, 1987.

Charles, C. D., Pahnke, K., Zahn, R., Mortyn, P., Ninnemann, U., and Hodell, D.: Millennial scale evolution of the Southern Ocean chemical divide, Quat. Sci. Rev., 29, 399-409, 2010.

Clark, P. U., Marshall, S. J., Clarke, G. K., Hostetler, S. W., Licciardi, J. M., and Teller, J. T.: Freshwater forcing of abrupt climate change during the last glaciation, Science, 293, 283-287, 2001.

Dansgaard, W., Johnsen, S., Clausen, H., Dahl-Jensen, D., Gundestrup, N., Hammer, C., Hvidberg, C., Steffensen, J., Sveinbjörnsdottir, A., and Jouzel, J.: Evidence for general instability of past climate from a 250-kyr ice-core record, Nature, 364, 218-220, 1993.
Elderfield, H. and Ganssen, G.: Past temperature and $\delta^{18} \mathrm{O}$ of surface ocean waters inferred from foraminiferal $\mathrm{Mg} / \mathrm{Ca}$ ratios, Nature, 405, 442-445, 2000.

Eynaud, F., de Abreu, L., Voelker, A., Schönfeld, J., Salgueiro, E., Turon, J.-L., Penaud, A., Toucanne, S., Naughton, F., Sánchez Goñi, M. F., Malaizé, B., and Cacho, I.: Position of the Polar Front along the western Iberian margin during key cold episodes of the last $45 \mathrm{ka}$, Geochem. Geophys. Geosyst., 10, Q07U05, doi:10.1029/2009gc002398, 2009.

Ezat, M. M., Rasmussen, T. L., and Groeneveld, J.: Persistent intermediate water warming during cold stadials in the southeastern Nordic seas during the past 65 k.y, Geology, 42, 663-666, doi:10.1130/g35579.1, 2014.

Ferretti, P., Crowhurst, S. J., Hall, M. A., and Cacho, I.: North Atlantic millennial-scale climate variability 910 to $790 \mathrm{ka}$ and the role of the equatorial insolation forcing, Earth Planet. Sci. Lett., 293, 28-41, 2010.

Ganopolski, A. and Rahmstorf, S.: Rapid changes of glacial climate simulated in a coupled climate model, Nature, 409, 153$158,2001$.

Grousset, F. E., Cortijo, E., Huon, S., Hervé, L., Richter, T., Burdloff, D., Duprat, J., and Weber, O.: Zooming in on Heinrich Layers, Paleoceanography, 16, 240-259, doi:10.1029/2000pa000559, 2001.

Hátún, H., Sandø, A. B., Drange, H., Hansen, B., and Valdimarsson, H.: Influence of the Atlantic Subpolar Gyre on the Thermohaline Circulation, Science, 309, 1841-1844, doi:10.1126/science.1114777, 2005.

Heinrich, H.: Origin and consequences of cyclic ice rafting in the Northeast Atlantic Ocean during the past 130000 years, Quaternary Res., 29, 142-152, 1988.

Hernández-Almeida, I., Sierro, F. J., Cacho, I., and Flores, J. A.: Impact of suborbital climate changes in the North Atlantic on ice sheet dynamics at the Mid-Pleistocene Transition, Paleoceanography, 27, PA3214, doi:10.1029/2011pa002209, 2012.

Hernández-Almeida, I., Bjørklund, K. R., Sierro, F. J., Filippelli, G. M., Cacho, I., and Flores, J. A.: A high resolution opal and radiolarian record from the subpolar North Atlantic during the MidPleistocene Transition (1069-779 ka): Palaeoceanographic implications, Palaeogeogr., Palaeoclimatol., Palaeoecol., 391, Part A, 49-70, doi:10.1016/j.palaeo.2011.05.049, $2013 \mathrm{a}$.

Hernández-Almeida, I., Sierro, F. J., Flores, J.-A., Cacho, I., and Filippelli, G. M.: Palaeoceanographic changes in the North Atlantic during the Mid-Pleistocene Transition (MIS 31-19) as inferred from planktonic foraminiferal and calcium carbonate records, Boreas, 42, 140-159, doi:10.1111/j.1502-3885.2012.00283.x, 2013 b.

Hillaire-Marcel, C., de Vernal, A., and McKay, J.: Foraminifer isotope study of the Pleistocene Labrador Sea, northwest North Atlantic (IODP Sites 1302/03 and 1305), with emphasis on paleoceanographical differences between its "inner" and "outer" basins, Mar. Geol., 279, 188-198, 2011.

Horikawa, K., Asahara, Y., Yamamoto, K., and Okazaki, Y.: Intermediate water formation in the Bering Sea during glacial periods: Evidence from neodymium isotope ratios, Geology, 38, 435-438, doi:10.1130/g30225.1, 2010.

Jonkers, L., Brummer, G.-J. A., Peeters, F. J. C., van Aken, H. M., and De Jong, M. F.: Seasonal stratification, shell flux, and oxygen isotope dynamics of left-coiling N. pachyderma and T. quin- 
queloba in the western subpolar North Atlantic, Paleoceanography, 25, PA2204, doi:10.1029/2009pa001849, 2010a.

Jonkers, L., Moros, M., Prins, M. A., Dokken, T., Dahl, C. A., Dijkstra, N., Perner, K., and Brummer, G.-J. A.: A reconstruction of sea surface warming in the northern North Atlantic during MIS 3 ice-rafting events, Quantenary Sci. Rev., 29, 1791-1800, 2010 b.

Kaspi, Y., Sayag, R., and Tziperman, E.: A "triple sea-ice state" mechanism for the abrupt warming and synchronous ice sheet collapses during Heinrich events, Paleoceanography, 19, PA3004, doi:10.1029/2004pa001009, 2004.

Kleiven, H. F., Hall, I. R., McCave, I. N., Knorr, G., and Jansen, E.: Coupled deep-water flow and climate variability in the middle Pleistocene North Atlantic, Geology, 39, 343-346, 2011.

Kohfeld, K. E., Fairbanks, R. G., Smith, S. L., and Walsh, I. D.: Neogloboquadrina pachyderma (sinistral coiling) as paleoceanographic tracers in polar oceans: rvidence from northeast water polynya plankton tows, sediment traps, and surface sediments, Paleoceanography, 11, 679-699, 1996.

Kozdon, R., Eisenhauer, A., Weinelt, M., Meland, M. Y., and Nürnberg, D.: Reassessing $\mathrm{Mg} / \mathrm{Ca}$ temperature calibrations of Neogloboquadrina pachyderma (sinistral) using paired $\delta^{44 / 40} \mathrm{Ca}$ and $\mathrm{Mg} / \mathrm{Ca}$ measurements, Geochem. Geophys. Geosyst., 10, Q03005, doi:10.1029/2008gc002169, 2009.

Li, C., Battisti, D. S., Schrag, D. P., and Tziperman, E.: Abrupt climate shifts in Greenland due to displacements of the sea ice edge, Geophys. Res. Lett., 32,L19702, doi:10.1029/2005GL023492, 2005.

Lisiecki, L. E. and Raymo, M. E.: A Pliocene-Pleistocene stack of 57 globally distributed benthic $\delta^{18} \mathrm{O}$ records, Paleoceanography, 20, PA1003, doi:10.1029/2004PA001071, 2005.

Liu, Z., Otto-Bliesner, B. L., He, F., Brady, E. C., Tomas, R., Clark, P. U., Carlson, A. E., Lynch-Stieglitz, J., Curry, W., Brook, E., Erickson, D., Jacob, R., Kutzbach, J., and Cheng, J.: Transient Simulation of Last Deglaciation with a New Mechanism for Bølling-Allerød Warming, Science, 325, 310-314, doi:10.1126/science.1171041, 2009.

Locarnini, R. A., Mishonov, A. V., Antonov, J. I., Boyer, T. P., Garcia, H. E., Baranova, O. K., Zweng, M. M., Paver, C. R., Reagan, J. R., Johnson, D. R., Hamilton, M., and Seidov, D.: World Ocean Atlas 2013, Volume 1: Temperature, edited by: Levitus, S., NOAA Atlas NESDIS, 73, 40 pp., 2013.

MacAyeal, D. R., Scambos, T. A., Hulbe, C. L., and Fahnestock, M. A.: Catastrophic ice-shelf break-up by an iceshelf-fragment-capsize mechanism, J. Glaciol., 49, 22-36, doi:10.3189/172756503781830863, 2003.

Malmberg, S. A.: The water masses between Iceland and Greenland, J. Mar. Res., 9, 127-140, 1985.

Manabe, S. and Stouffer, R. J.: Coupled ocean-atmosphere model response to freshwater input: Comparison to Younger Dryas Event, Paleoceanography, 12, 321-336, doi:10.1029/96pa03932, 1997.

Marcott, S. A., Clark, P. U., Padman, L., Klinkhammer, G. P., Springer, S. R., Liu, Z., Otto-Bliesner, B. L., Carlson, A. E., Ungerer, A., Padman, J., He, F., Cheng, J., and Schmittner, A.: Ice-shelf collapse from subsurface warming as a trigger for Heinrich events, P. Natl. Acad. Sci., 108, 13415-13419, doi:10.1073/pnas.1104772108, 2011.

Marshall, S. J. and Koutnik, M. R.: Ice sheet action versus reaction: Distinguishing between Heinrich events and Dansgaard-
Oeschger cycles in the North Atlantic, Paleoceanography, 21, PA2021, doi:10.1029/2005pa001247, 2006.

McClymont, E. L., Rosell-Melé, A., Haug, G. H., and Lloyd, J. M.: Expansion of subarctic water masses in the North Atlantic and Pacific oceans and implications for midPleistocene ice sheet growth, Paleoceanography, 23, PA4214, doi:10.1029/2008pa001622, 2008.

Mignot, J., Ganopolski, A., and Levermann, A.: Atlantic Subsurface Temperatures: Response to a Shutdown of the Overturning Circulation and Consequences for Its Recovery, J. Climate, 20, 4884-4898, doi:10.1175/JCLI4280.1, 2007.

Mix, A. C. and Fairbanks, R. G.: North Atlantic surface-ocean control of Pleistocene deep-ocean circulation, Earth Planet. Sci. Lett., 73, 231-243, 1985.

Moros, M., Kuijpers, A., Snowball, I., Lassen, S., Bäckström, D., Gingele, F., and McManus, J.: Were glacial iceberg surges in the North Atlantic triggered by climatic warming?, Mar. Geol., 192, 393-417, 2002.

Naafs, B. D. A., Hefter, J., and Stein, R.: Millennial-scale ice rafting events and Hudson Strait Heinrich(-like) Events during the late Pliocene and Pleistocene: a review, Quantenary Sci. Rev., 80, 128, doi:10.1016/j.quascirev.2013.08.014, 2013.

Nürnberg, D.: Magnesium in tests of Neogloboquadrina pachyderma sinistral from high northern and southern latitudes, J. Foramin. Res., 25, 350-368, doi:10.2113/gsjfr.25.4.350, 1995.

Nyland, B. F., Jansen, E., Elderfield, H., and Andersson, C.: Neogloboquadrina pachyderma (dex. and sin.) $\mathrm{Mg} / \mathrm{Ca}$ and $\delta^{18} \mathrm{O}$ records from the Norwegian Sea, Geochem. Geophys. Geosyst., 7, Q10P17, doi:10.1029/2005gc001055, 2006.

Oppo, D. W. and Lehman, S. J.: Mid-Depth Circulation of the Subpolar North Atlantic During the Last Glacial Maximum, Science, 259, 1148-1152, 1993.

Paillard, D. L. and Yiou, P.: Macintosh program performs timeseries analysis, Eos Transactions, American Geophysical Union, 77, p. 379, doi:10.1029/96EO00259, 1996.

Peck, V. L., Hall, I. R., Zahn, R., Elderfield, H., Grousset, F., Hemming, S. R., and Scourse, J. D.: High resolution evidence for linkages between NW European ice sheet instability and Atlantic Meridional Overturning Circulation, Earth Planet. Sci. Lett., 243, 476-488, 2006.

Peck, V. L., Hall, I. R., Zahn, R., and Elderfield, H.: Millennialscale surface and subsurface paleothermometry from the northeast Atlantic, 55-8 ka BP, Paleoceanography, 23, PA3221, doi:10.1029/2008pa001631, 2008.

Pena, L. D., Calvo, E., Cacho, I., Eggins, S., and Pelejero, C.: Identification and removal of $\mathrm{Mn}-\mathrm{Mg}$-rich contaminant phases on foraminiferal tests: Implications for $\mathrm{Mg} / \mathrm{Ca}$ past temperature reconstructions, Geochem. Geophys. Geosyst., 6, Q09P02, doi:10.1029/2005gc000930, 2005.

Petersen, S. V., Schrag, D. P., and Clark, P. U.: A new mechanism for Dansgaard-Oeschger cycles, Paleoceanography, 28, doi:10.1029/2012PA002364, 2013.

Rasmussen, T. L. and Thomsen, E.: The role of the North Atlantic Drift in the millennial timescale glacial climate fluctuations, Palaeogeogr., Palaeoclimatol., Palaeoecol., 210, 101-116, 2004.

Rignot, E. and Jacobs, S. S.: Rapid Bottom Melting Widespread near Antarctic Ice Sheet Grounding Lines, Science, 296, 20202023, doi:10.1126/science.1070942, 2002. 
Risebrobakken, B., Dokken, T., Smedsrud, L. H., Andersson, C., Jansen, E., Moros, M., and Ivanova, E. V.: Early Holocene temperature variability in the Nordic Seas: The role of oceanic heat advection versus changes in orbital forcing, Paleoceanography, 26, PA4206, doi:10.1029/2011pa002117, 2011.

Ruddiman, W. F.: Late Quaternary deposition of ice-rafted sand in the subpolar North Atlantic (lat $40^{\circ}$ to $65^{\circ} \mathrm{N}$ ), Geol. Soc. Am. Bull., 88, 1813-1827, 1977.

Ruddiman, W. F. and McIntyre, A.: The North Atlantic Ocean during the last deglaciation, Palaeogeogr., Palaeoclimatol., Palaeoecol., 35, 145-214, 1981.

Rühlemann, C., Mulitza, S., Lohmann, G., Paul, A., Prange, M., and Wefer, G.: Intermediate depth warming in the tropical Atlantic related to weakened thermohaline circulation: Combining paleoclimate data and modeling results for the last deglaciation, Paleoceanography, 19, PA1025, doi:10.1029/2003pa000948, 2004.

Schlitzer, R.: Ocean Data View, available at: http://odv.awi.de, last access: 9 November 2014, 2008.

Schmidt, M. W., Spero, H. J., and Lea, D. W.: Links between salinity variation in the Caribbean and North Atlantic thermohaline circulation, Nature, 428, 160-163, 2004.

Schmidt, M. W., Vautravers, M. J., and Spero, H. J.: Rapid subtropical North Atlantic salinity oscillations across DansgaardOeschger cycles, Nature, 443, 561-564, 2006.

Schmidt, M. W., Chang, P., Hertzberg, J. E., Them, T. R., Ji, L., and Otto-Bliesner, B. L.: Impact of abrupt deglacial climate change on tropical Atlantic subsurface temperatures, P. Natl. Acad. Sci., 109, 14348-14352, doi:10.1073/pnas.1207806109, 2012.

Shackleton, N.: Attainment of isotopic equilibrium between ocean water and the benthonic foraminifera genus Uvigerina: isotopic changes in the ocean during the last glacial, Colloques Internationaux du CNRS, 219, 203-209, 1974.

Shaffer, G., Olsen, S. M., and Bjerrum, C. J.: Ocean subsurface warming as a mechanism for coupling Dansgaard-Oeschger climate cycles and ice-rafting events, Geophys. Res. Lett., 31, L24202, doi:10.1029/2004g1020968, 2004.
Simstich, J., Sarnthein, M., and Erlenkeuser, H.: Paired $\delta^{18} \mathrm{O}$ signals of Neogloboquadrina pachyderma (s) and Turborotalita quinqueloba show thermal stratification structure in Nordic Seas, Mar. Micropaleontol., 48, 107-125, 2003.

Smith, L. M., Andrews, J. T., Castañeda, I. S., Kristjánsdóttir, G. B., Jennings, A. E., and Sveinbjörnsdóttir, Á. E.: Temperature reconstructions for SW and N Iceland waters over the last $10 \mathrm{cal} \mathrm{ka}$ based on $\delta^{18} \mathrm{O}$ records from planktic and benthic Foraminifera, Quantenary Sci. Rev., 24, 1723-1740, 2005.

Thornalley, D. J., Elderfield, H., and McCave, I. N.: Holocene oscillations in temperature and salinity of the surface subpolar North Atlantic, Nature, 457, 711-714, 2009.

Vaughan, D. G. and Doake, C. S. M.: Recent atmospheric warming and retreat of ice shelves on the Antarctic Peninsula, Nature, 379, 328-331, 1996.

Venz, K. A., Hodell, D. A., Stanton, C., and Warnke, D. A.: A 1.0 Myr Record of Glacial North Atlantic Intermediate Water Variability from ODP Site 982 in the Northeast Atlantic, Paleoceanography, 14, 42-52, 1999.

Voelker, A. H. L., Rodrigues, T., Billups, K., Oppo, D., McManus, J., Stein, R., Hefter, J., and Grimalt, J. O.: Variations in midlatitude North Atlantic surface water properties during the midBrunhes (MIS 9-14) and their implications for the thermohaline circulation, Clim. Past, 6, 531-552, doi:10.5194/cp-6-531-2010, 2010.

Volkmann, R. and Mensch, M.: Stable isotope composition $\left(\delta^{18} \mathrm{O}\right.$, $\delta^{13} \mathrm{C}$ ) of living planktic foraminifers in the outer Laptev Sea and the Fram Strait, Mar. Micropaleontol., 42, 163-188, 2001.

Zweng, M. M., Reagan, J. R., Antonov, J. I., Locarnini, R. A., Mishonov, A. V., Boyer, T. P., Garcia, H. E., Baranova, O. K., Johnson, D. R., Seidov, D., and Biddle, M. M.: World Ocean Atlas 2013, Volume 2: Salinity, edited by: Levitus, S., NOAA Atlas NESDIS, 74, 39 pp., 2013. 